\title{
KOMUNIKASI DALAM INTERAKSI SOSIAL (Analisis Etika Komunikasi Dalam Perspektif Islam)
}

\author{
Oleh: Faridah ${ }^{1}$ \\ ${ }^{1}$ Institut Agama Islam Muhammadiyah Sinjai, \\ J1. Sultan Hasanuddin, No. 20 Balangnipa, Sinjai \\ E-Mail: andifaridah81gmail.com, Tlp: +6285242364718
}

\begin{abstract}
Abstrak
Komunikasi merupakan satu syarat utama dalam keberhasilan berinteraksi dengan lingkungan sekitar. Komunikasi merupakan salah satu bentuk kebutuhan primer manusia karena setiap elemen kehidupan manusia membutuhkan komunikasi. Kegagalan dalam komunikasi dapat berakibat pada kerenggangan, kekacauan, dan ketidakharmonisan dalam hidup baik dalam rumah tangga, keluarga, maupun dalam bermasyarakat. Sebaliknya komunikasi yang baik akan menciptakan harmoni kehidupan yang akan mengantarkan pada kebahagiaan hidup baik dunia maupun akhirat. Menyikapi perkembangan komunikasi terutama karena kemajuan teknologi dan media komunikasi, dewasa ini telah banyak ditemukan kegagalan dalam komunikasi. Hal ini merupakan salah satu akibat jauhnya atau kekurangtahuan/kekurangpahaman komunikator tentang etika-etika komunikasi. Sehingga mustahil bisa ditemukan penerapan etika komunikasi dalam interaksi yang berlangsung. Islam sebagai rahmat bagi semesta alam telah mengatur tata cara berkomunikasi yang merupakan panduan etika komunikasi yang telah dicontohkan oleh Rasulullah Saw. Etika komunikasi tersebut di antaranya adalah Tidak memisahkan antara dakwah bi al-lisān, bi al-qalām dengan perbuatan. Hal ini didasarkan pada QS al-Baqarah/2: 44 dan al-Saf/61: 2-3, tidak mencerca sesembahan lawan (non muslim), didasarkan pada QS al-An'äm/6: 108, tidak melakukan diskriminasi sosial, didasarkan pada QS 'Abasa/87: 1-2, QS al-An'ām/6: 52. dan QS alKahfi/18: 28, Tidak menyampaikan hal-hal yang tidak diketahui kebenarannya, didasarkan pada QS al-Isrā'/17: 36. Selain Etika Komunikasi, Islam juga menganjurkan beberapa jenis komunikasi yang sebaiknya dilakukan dalam interaksi sosial, jenis komunikasi tersebut telah dijelaskan dalam al-Quran dan telah diaplikasikan oleh para Nabiullah seperti Qaulan layyinan (perkataan yang lembut), QS Tăha/20: 43-44, Qaulan baligha (perkataan yang membekas pada jiwa), QS al-Nisā'/4: 63. dan Qaulan ma'rüfan (perkataan yang baik) yakni QS al-Nisā'/4: 5.
\end{abstract}

\section{Kata Kunci: Komunikasi, Interaksi Sosial, Etika Komunikasi, Perspektif Islam}

\section{PENDAHULUAN}

\section{A. Latar Belakang Masalah}

$\mathrm{M}$

elakukan interaksi sosial dengan lingkungan merupakan salah satu kebutuhan manusia sebagai makhluk sosial (Totok Jumantoro, 2001: 83), dengan berinteraksi berarti manusia telah menjalani suatu proses komunikasi yakni proses membagi ide, informasi, dan pesan dengan orang lain pada tempat dan 
waktu yang tertentu atau proses tukar menukar pemahaman, opini, ide, dan pesan (baik berupa perintah atau larangan, atau hanya sekedar informasi) (M. Tata Taufik, 2012: 32).

Komunikasi merupakan satu syarat utama dalam berinteraksi dengan lingkungan sekitar, suatu kebutuhan manusia yang tidak bisa disangsikan. Karena setiap elemen kehidupan manusia membutuhkan komunikasi, kegagalan dalam komunikasi dapat berakibat pada kerenggangan, kekacauan, dan ketidakharmonisan dalam hidup baik dalam rumah tangga, keluarga, maupun dalam bermasyarakat. Sebaliknya komunikasi yang baik akan menciptakan harmoni kehidupan yang akan mengantarkan pada kebahagiaan hidup baik dunia maupun akhirat.

Kebutuhan akan komunikasi efektif menimbulkan berbagai kajian tentang komunikasi yakni berupa studi komunikasi yang diyakini berkembang sebagai bentuk kelanjutan tradisi retorika pada masa Yunani kuno. Namun, beberapa ahli komunikasi memandang bahwa retorika hanya bagian dari komunikasi (Kadar Nurjaman dan Khaerul Umam, 2012: 5-6). Kajian komunikasi sebagai suatu disiplin ilmu diketahui dari beberapa literatur menyatakan bahwa studi tentang komunikasi sesungguhnya berawal dari Barat yang menyatakan Walter Lippman sebagai bapak komunikasi yang lahir tahun 1889 di Jerman (M. Tata Taufik, 2012: 21).

Kehadiran ilmu komunikasi sebagai suatu disiplin ilmu tersendiri merupakan suatu hal yang menggembirakan mengingat peran dan fungsi komunikasi dalam kehidupan yang sangat sentral. Salah satu yang dapat di jadikan asumsi adalah kebutuhan manusia akan teknik berkomunikasi efektif yang dapat dipelajari dan ditemukan dalam salah satu bidang kajian ilmu komunikasi yakni public relation (Kadar Nurjaman dan Khaerul Umam, 2012: 46-49).

Adapun dalam dunia Islam, teknik-teknik berkomunikasi sudah bukan hal yang asing lagi termasuk tentang tata cara berkomunikasi yang efektif karena hal ini telah dicontohkan oleh Rasulullah Saw dalam menjalankan aktivitas dakwahnya. Rasulullah Saw dengan kemampuan retorikanya telah mampu menciptakan suatu kecemerlangan yang luar biasa di tengah kehidupan masyarakat Arab jahiliah sehingga mampu membangun suatu peradaban yang gemilang.

Konsep Islam tentang komunikasi berdasarkan uraian sebelumnya merupakan suatu hal yang selayaknya dikaji dan dianalisis utamanya bagi umat Islam agar umat Islam mampu meraih peluang sebagai umat terbaik yang salah satu indikator keberhasilannya dapat dicapai dengan komunikasi yang efektif. 


\section{B. Rumusan Masalah}

1. Bagaimana konsep dan etika komunikasi dalam perspektif Islam?

2. Bagaimana bentuk-bentuk komunikasi dalam perspektif Islam?

3. Bagaimana urgensi komunikasi dalam perspektif Islam?

\section{Tujuan Penulisan}

Tujuan penelitian dan penulisan jurnal ini adalah untuk menambah pengetahuan dan mendeskripsikan tentang

1. Konsep komunikasi dalam perspektif Islam.

2. Bentuk-bentuk komunikasi dalam perspektif Islam.

3. Urgensi komunikasi dalam perspektif Islam.

\section{PEMBAHASAN}

\section{A. Konsep dan Etika Komunikasi dalam Perspektif Islam}

Analisis kebutuhan manusia akan komunikasi mengisyaratkan bahwa komunikasi sesungguhnya ada bersamaan dengan kehadiran manusia di muka bumi ini, bahkan sebelum manusia dilahirkan telah terjadi komunikasi antar manusia dengan penciptanya. Hal ini dapat dilihat dari $Q S$ al- $A$ 'räf/7: 172.

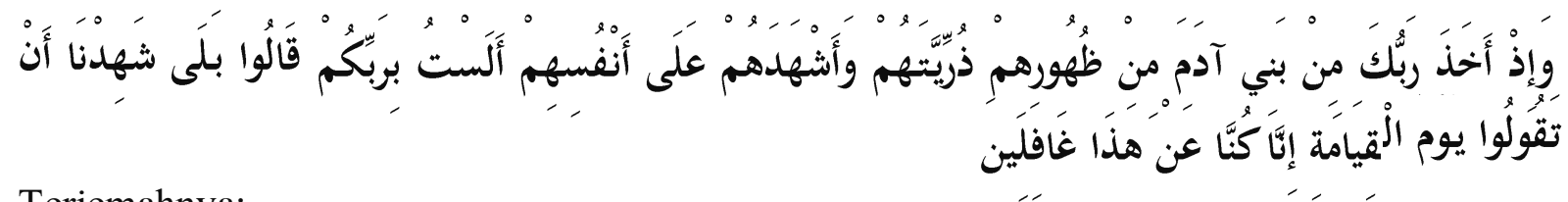

Terjemahnya:

Dan (ingatlah), ketika Tuhan mu mengeluarkan keturunan anak-anak Adam dari sulbi mereka dan Allah mengambil kesaksian terhadap jiwa mereka (seraya berfirman): "Bukankah aku ini Tuhan mu?" mereka menjawab: "Betul (Engkau Tuban kami), Kami menjadi saksi". (kami lakukan yang demikian itu) agar di hari kiamat kamu tidak mengatakan: "Sesungguhnya Kami (Bani Adam) adalah orang-orang yang lengah terhadap ini (keesaan Tuhan). (Departemen Agama RI, 2012: 174).

Ayat tersebut menggambarkan bahwa manusia telah melakukan komunikasi ketika masih berada dalam kandungan dan itulah komunikasi pertama yang dilakukan oleh manusia yakni komunikasi dengan Tuhan-nya dalam bentuk pengakuan atas keberadaan Tuhan sebagai Sang Pencipta.

Setelah komunikasi dalam kandungan, komunikasi kedua manusia adalah ketika manusia lahir ke dunia ini, suara tangisan yang diperdengarkan mengisyaratkan kehadirannya kepada orang di sekitarnya, suatu informasi yang diberikan kepada kedua orang tuanya atau 
orang yang ada di sekelilingnya dan sekaligus pernyataan untuk meminta pertolongan kepada orang lain (Arifuddin Tike, 2012: 1).

Pernyataan dan tangisan dari manusia ketika masih bayi tersebut memberikan pemahaman kalau ternyata komunikasi merupakan suatu hal yang tidak bisa dipisahkan dari kehidupan manusia. Menurut Anwar Arifin, komunikasi sebagai fenomena sosial telah hadir sejak perjumpaan Adam dan Hawa di muka bumi. Bahkan eksistensi nya tidak dapat dielakkan, karena perjumpaan itu sendiri memerlukan komunikasi, agar dapat berlanjut menjadi persahabatan, pertemanan, persekutuan atau perkawinan. Justru itu banyak yang menyebut komunikasi sebagai perekat hidup bersama kehadiran dan pertemuan Adam dan Hawa (Anwar Arifin, t.th.: 42).

Komunikasi merupakan suatu kebutuhan mutlak bagi manusia yang tidak bisa dielakkan lagi. Komunikasi tidak bisa dianggap sekedar wacana yang diperdebatkan kehadirannya, sebab segala sesuatu yang berkaitan dengan kebutuhan manusia membutuhkan komunikasi di mana komunikasi tersebut menjadi syarat utama manusia agar mampu berinteraksi dengan manusia lainnya sebagai makhluk sosial.

Pentingnya komunikasi dalam kehidupan dalam rangka mewujudkan berbagai bentuk kebutuhan manusia, salah satunya dapat dilihat dalam bentuk pelaksanaan dakwah yang dalam bahasa komunikasi disebut juga dengan komunikasi Islam yakni proses penyampaian pesan antara manusia yang didasarkan pada ajaran Islam (A. Abdul Muis, 2001: 66).

Di samping itu, dalam Islam telah diatur tata cara berkomunikasi yang merupakan panduan etika komunikasi yang telah dicontohkan oleh Rasulullah yang dikemukakan oleh Mustafa Yaqub seperti dikutip Suf Kasman, diantaranya yaitu:

1. Tidak memisahkan antara dakwah bi al-lisān, bi al-qalam dengan perbuatan. Hal ini didasarkan pada QS al-Baqarah/2: 44 dan QS al-Ṣäf/61: 2-3.

2. Tidak mencerca sesembahan lawan (non muslim), didasarkan pada $Q S$ al-An'ām/6: 108.

3. Tidak melakukan diskriminasi sosial, didasarkan pada $Q S$ 'Abasa/87: 1-2, QS alAn'ām/6: 52 dan QS al-Kahfi/18: 28.

4. Tidak menyampaikan hal-hal yang tidak diketahui kebenarannya, didasarkan pada $Q S$ al-Isrä'/17: 36(Suf Kasman, 2004: 223-224).

Pernyataan tentang persaksian manusia di dalam kandungan, suara tangisan bayi yang baru lahir sampai pada etika komunikasi yang ditetapkan dalam al-Qur'an, di samping itu masih banyak ungkapan tersirat dan tersurat lainnya yang dapat dianalisis dalam al-Qur'an. 
Di samping itu penjelasan dari sunnah-sunnah Rasulullah telah cukup jelas mengemukakan bahwa di dalam Islam konsep-konsep tentang komunikasi bukan hal yang baru meskipun ada yang masih tersirat namun semua hanya membutuhkan kajian yang lebih mendalam untuk membahasnya lebih spesifik dalam kajian tentang komunikasi dalam Islam.

\section{B. Bentuk-Bentuk Komunikasi dalam Perspektif Islam}

Komunikasi merupakan jembatan untuk menyampaikan informasi dari satu pihak ke pihak lain, yakni dari komunikator kepada komunikan baik dari Tuhan kepada hambanya, maupun antar sesama manusia sehingga pengirim pesan tersebut dapat menyampaikan informasi atau ajaran kepada komunikannya (Arifuddin Tike, 2012: 2).

Terjadinya proses penyampaian informasi atau pesan dari komunikator kepada komunikan dengan keragaman seperti yang dijelaskan pada definisi komunikasi tersebut menggambarkan bahwa komunikasi sebagai suatu jembatan untuk menyampaikan suatu informasi atau pesan terdiri dari beberapa bentuk diantaranya yaitu komunikasi Tuhan kepada manusia dengan informasi dan pesan berupa pedoman hidup baik itu perintah maupun larangan yang disampaikan melalui Malaikat Jibril kepada Nabi Muhammad Saw yang tertuang dalam al-Qur'an dan Sunnah. Respon dari perintah dan larangan tersebut diaktualisasikan dalam bentuk ibadah kepada Tuhan sehingga tercipta hubungan. Hubungan yang terjadi antara hamba dan Sang Pencipta inilah yang dalam komunikasi disebut dengan komunikasi transcendental (Arifuddin Tike, 2012: 3).

Proses komunikasi dari Tuhan kepada hambaNya berupa informasi dan pesan dari Tuhan yang disampaikan melalui malaikat Jibril kepada Nabi Muhammad merupakan suatu tahapan komunikasi. Selanjutnya informasi atau pesan tersebut disampaikan oleh Nabi Muhammad Saw kepada umat manusia, sehingga pesan tersebut dapat diketahui dan diaplikasikan dalam kehidupan umat. Kegiatan-kegiatan komunikasi Nabi Muhammad Saw tersebut merupakan bentuk komunikasi kenabian.

Adapun dalam menyampaikan informasi dan pesan tersebut Nabi Muhammad Saw melakukan berbagai langkah atau metode atau beberapa cara berkomunikasi baik dengan menggunakan bahasa verbal maupun bahasa non-verbal. Ragam model komunikasi yang dilakukan Nabi Muhammad Saw merupakan penjabaran dari perintah Allah Swt dalam alQuran seperti model penyampaian suatu pesan sesuai dengan kondisi orang yang dihadapi serta memperhatikan tingkat pemahamannya di antaranya, yaitu; 
1. Qaulan layyinan (perkataan yang lembut), QS Țāha/20: 43-44.

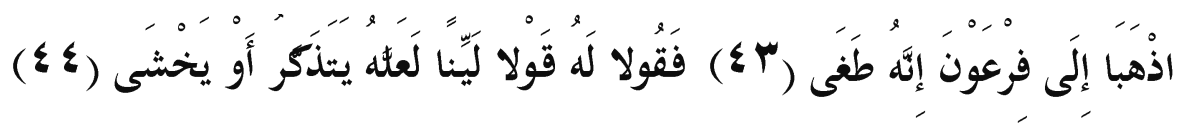

Terjemahnya:

'Pergilah kamu berdua kepada Fir'aun, Sesungguhnya Dia telah melampaui batas, Maka berbicaralah kamu berdua kepadanya dengan kata-kata yang lemah lembut, Mudah-mudahan ia ingat atau takut” (Departemen Agama RI, 2012: 315).

2. Qaulan maisura (perkataan yang ringan) $Q S$ al-Isrä'/17: 28.

Terjemahnya:

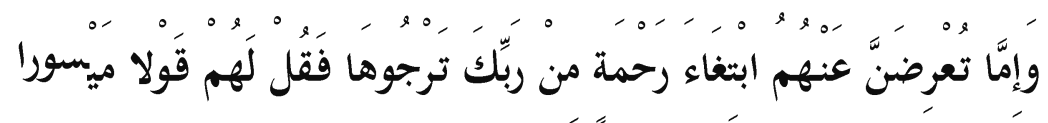

"Dan jika kamu berpaling dari mereka untuk memperoleh rahmat dari Tuhanmu yang kamu harapkan, Maka Katakanlah kepada mereka ucapan yang pantas" (Departemen Agama RI, 2012: 286).

3. Qaulan baligha (perkataan yang membekas pada jiwa) QS al-Nisā'/4: 63 .

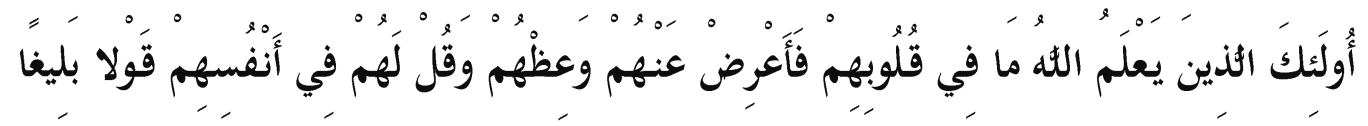

Terjemahnyá:

"Mereka itu adalah orang-orang yang Allah mengetahui apa yang di dalam hati mereka. karena itu berpalinglah kamu dari mereka, dan berilah mereka pelajaran, dan Katakanlah kepada mereka Perkataan yang berbekas pada jiwa mereka" (Departemen Agama RI, 2012: 189).

4. Qaulan ma'rufan (perkataan yang baik) yakni pada QS al-Nisä'4: 5 .

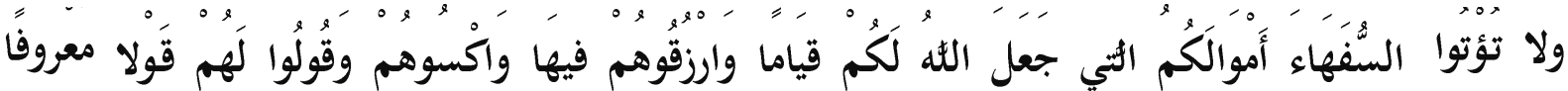

Terjemahnya:

"Dan janganlah kamu serahkan kepada orang-orang yang belum sempurna akalnya, harta (mereka yang ada dalam kekuasaanmu) yang dijadikan Allah sebagai pokok kehidupan. berilah mereka belanja dan pakaian (dari hasil harta itu) dan ucapkanlah kepada mereka kata-kata yang baik" (Departemen Agama RI, 2012: 78).

Beberapa ayat tersebut merupakan suatu perintah tata cara berkomunikasi dalam Islam yang dijelaskan dalam al-Qur'an, tata cara komunikasi tersebut telah dicontohkan Nabi Muhammad Saw dalam kehidupan sehari-hari, baik dalam kehidupan keluarga maupun dalam kehidupan bermasyarakat. Segala tindak-tanduk Rasulullah Saw tersebut sesungguhnya harus menjadi acuan bagi umat Islam dalam berinteraksi baik kepada individu, kelompok, masyarakat, dan alam sekitar terutama kepada Tuhan-nya.

Di antara sikap Nabi Muhammad Saw yang merupakan panduan dan teladan umat Islam dalam berkomunikasi. Sikap berbahasa Nabi Saw yang lemah lembut, serta 
menimbulkan rasa simpati yang dalam bagi siapa saja yang mendengar beliau berkata-kata, berdakwah dan berkhotbah. Kiprah komunikasi beliau sangat persuasif, cepat akrab dan bersahabat. Kalimat-kalimat yang teratur keluar dari organ-organ suara beliau merefleksikan dan mengekspresikan kearifan dan kebijaksanaan dalam pesan-pesan yang menyentuh (mau'izah hasanah). Rasulullah Saw merupakan panutan berkomunikasi efektif melalui bahasa, baik dalam khotbah maupun dalam tutur sapa sehari-hari (Djamalul Abidin Ass, 1996: 4).

Di samping itu, Rasulullah Saw juga merupakan teladan dalam sikap dan perbuatan. Rasulullah Saw yang ramah, santun, tawadhu, dermawan baik di kalangan muslim maupun non-muslim, pemaaf, bijaksana dalam bertindak dan akhlak mulia yang lain yang benarbenar menjadikannya pribadi yang sangat mengagumkan (Tahir Ismail, 1996: 4). Pribadipribadi Rasulullah Saw inilah yang dianjurkan untuk diteladani utamanya bagi umat Islam seperti yang dinyatakan dalam $Q S$ al- $A$ hazāb/33:21.

Terjemahnya:

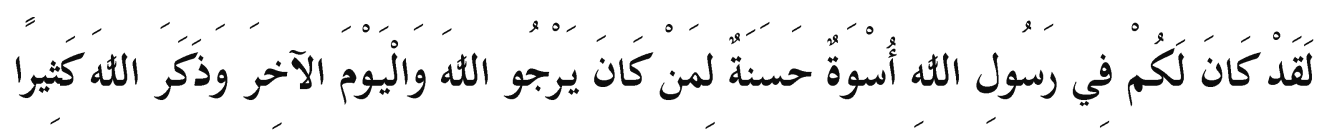

"Sesungguhnya telah ada pada (diri) Rasulullah itu suri teladan yang baik bagimu (yaitu) bagi orang yang mengharap (rahmat) Allah dan (kedatangan) hari kiamat dan

Dia banyak menyebut Allah" (Departemen Agama RI, 2012: 421).

Pada ayat tersebut, disampaikan tentang pentingnya meneladani Rasulullah Saw untuk mendapatkan rahmat dari Allah Swt. Salah satu yang sangat penting menjadi teladan dari Rasulullah Saw adalah bentuk-bentuk komunikasi beliau yang semestinya diaplikasikan dalam bentuk komunikasi-komunikasi yang umum dilakukan dalam kehidupan sehari-hari baik dalam komunikasi antara individu, komunikasi antara kelompok, maupun dalam komunikasi antar masyarakat.

Bentuk komunikasi yang umum dalam perspektif Islam diantaranya adalah komunikasi antara dai dan mad'u, yakni proses penyampaian informasi atau pesan antara dai dan mad'u baik itu dalam bentuk dialog maupun monolog. Adapun proses komunikasi tersebut, seperti yang telah dijelaskan terdiri atas dua bentuk yakni komunikasi dengan menggunakan bahasa verbal maupun dengan bahasa non verbal. Kemampuan memadukan dua jenis komunikasi ini memungkinkan terciptanya komunikasi yang efektif.

\section{Urgensi Komunikasi dalam Perspektif Islam}

Komunikasi merupakan aktivitas manusia sehari-hari, ibarat makan dan minum. Sehari saja tidak berkomunikasi, manusia akan mengalami kesulitan hidup (Kadar Nurjaman dan 
Khaerul Umam, 2017: 7). Demikian pentingnya komunikasi dalam kehidupan manusia karena sebagai makhluk sosial, manusia senantiasa ingin berhubungan dengan manusia lain, selalu ingin tahu lingkungan sekitarnya, ingin tahu apa yang terjadi di dalam dirinya serta ingin tahu penciptanya (Arifuddin Tike, 2012: 4).

Dalam perspektif Islam, komunikasi merupakan suatu hal yang sangat penting karena ajaran-ajaran Islam merupakan ajaran yang harus diserukan dan disampaikan yang dilakukan dengan jalan dakwah. Hal ini merupakan perintah Allah Swt dalam QS Äli 'Imrān/3: 104.

Terjemahnya:'

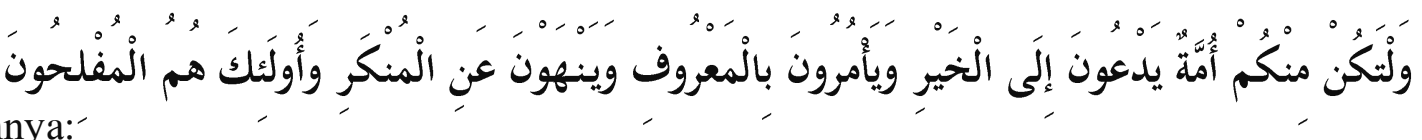

"Dan hendaklah ada di antara kamu segolongan umat yang menyeru kepada kebajikan, menyuruh kepada yang ma'ruf dan mencegah dari yang munkar, merekalah orang-orang yang beruntung" (Departemen Agama RI, 2012: 64).

Perintah dalam ayat ini hanya bisa dilakukan dengan jalan dakwah yang berarti harus berkomunikasi karena aktivitas menyeru, menyuruh, dan mencegah adalah bentuk-bentuk komunikasi baik itu dengan bahasa verbal (lisan) maupun bahasa nonverbal (teladan).

Dakwah merupakan suatu bentuk komunikasi dalam Islam yang dengan melakukannya suatu ajaran akan dapat disebarkan sehingga dapat terealisasi dalam kehidupan umat. Karena suatu ajaran yang baik apabila tidak didakwahkan tidak mustahil akan hilang, dan sebaliknya ajaran yang buruk dan sesat apabila di dakwahkan secara berkesinambungan dapat tersiar dan membudaya dalam masyarakat (Nurhidayat Muhammad Said, 2011: 59).

Pentingnya komunikasi sebagai suatu bentuk proses atau aktivitas dakwah juga dapat dipahami pada salah satu definisi operasional dakwah yaitu pentingnya mengkomunikasikan nilai-nilai ajaran Islam sebagai isi pesan dakwah yang perlu dipahami dan disikapi (Asep Muhyiddin Dan Agus Ahmad Safei, 2002: 30). Dalam hal ini komunikasi hendaknya dalam rangka mewujudkan keadilan, kejujuran, kesederhanaan, keberanian, kedamaian, etos kerja, amanah, kritis (prinsip tawashau bilhaq dan tawashau bi al-șabr ), amar ma'ruf (M. Tata Taufik, 2012: 15).

Namun, menyampaikan nilai-nilai Islam tidak mudah mencapai keberhasilan. Banyak pesan dakwah yang tidak sampai kepada khalayak karena dai tidak mampu berkomunikasi secara efektif, tidak mampu menuangkan pesannya dalam bahasa yang benar dan baik. Dakwah yang disajikannya kering, gersang, dan hambar. bahasanya tidak bergaya sehingga khalayaknya tidak memahami apa yang disampaikannya, minat dan interest khalayaknya 
hilang, dan komunikasi tidak terjalin. Dakwahnya seperti air di daun keladi (Djamalul Abidin Ass, 1996: 1).

Mengkaji hal ini, mengisyaratkan bahwa seorang dai hendaklah mempedulikan ramburambu dalam memilih kosa kata (diksi) dalam menyusun komposisi kalimat. Sehingga seorang dai dapat berdakwah berapi-api tetapi bahasanya tetap terkendali dan santun. Dalam dakwah, dai tidak boleh hanya sekedar mengandalkan tata bunyi, diksi, dan komposisi, tapi dai harus mempertimbangkan beberapa aspek termasuk penampilan diri dan perlu memahami komunikasi nonverbal yang meliputi isyarat dan gerak-gerik tubuh, ekspresi wajah, serta unsur-unsur lain (Djamalul Abidin Ass, 1996: 2). Hal ini pun mejadi kajian dalam komunikasi efektif yang mengungkapkan bahwa 55\% makna dari setiap pesan berasal dari bahasa tubuh visual (gerakan, sikap, dan ekspresi wajah). 38\% makna dalam setiap pesan berasal dari elemen non-verbal dari perkataan (vokal) yakni cara bagaimana kata-kata tersebut diucapkan melalui nada, pola, dan kecepatan suara. 7\% makna pesan berasal dari kata-kata atau isi pesannya (James Borg, 2010: 49).

Terpadunya antara komunikasi verbal dan non-verbal dari seorang dai akan lebih memungkinkan efektifnya dakwah yang dilakukan. Adapun kesuksesan suatu dakwah dapat dilihat dari bekas yang ditinggalkan dalam benak pendengarnya ataupun tercermin dalam tingkah laku mad'u. hal ini sejalan dengan komunikasi yang dianggap berhasil bila respons penerima mendekati apa yang dikehendaki oleh sumber yang menciptakan pesan (H. Usman Jasad, 2011: 39).

Suksesnya dakwah yang merupakan efek dari kemampuan dai melakukan komunikasi dengan baik, baik komunikasi verbal maupun non-verbal mengisyaratkan bahwa komunikasi merupakan suatu hal yang sangat penting dalam proses dakwah dalam rangka mewujudkan misi Islam sebagai rahmat bagi semesta alam. Karena ajaran-ajaran Islam apabila dikehendaki tersebar luas dan diaplikasikan dalam kehidupan umat sehingga terwujud misi Islam sebagai rahmat bagi semesta alam, haruslah melalui komunikasi.

\section{PENUTUP}

\section{A. Kesimpulan}

Konsep komunikasi dalam perspektif Islam belum ditemukan kajian nya secara spesifik, namun al-Qur'an telah mengisyaratkan bahwa sesungguhnya komunikasi itu telah ada bersamaan dengan kehadiran manusia di muka bumi ini, bahkan sebelum manusia dilahirkan telah terjadi komunikasi antar manusia dengan Penciptanya, hal ini dapat dilihat 
dari QS al-A'räf/7: 172. Di samping itu, di dalam al-Qur'an juga di jelaskan tentang etikaetika komunikasi yang seharusnya menjadi pedoman umat Islam dalam berkomunikasi.

Adapun bentuk-bentuk komunikasi dalam perspektif Islam berdasarkan hasil analisis dikemukakan terdiri dari komunikasi Ketuhanan (komunikasi transendental), komunikasi Nabi, komunikasi umum antar manusia dan komunikasi dengan alam sekitar.

Menurut Islam, komunikasi hendaknya dalam rangka mewujudkan keadilan, kejujuran, kesederhanaan, keberanian, kedamaian, etos kerja, amanah, kritis (prinsip tawashau bilhaq dan tawashau bi al-șabr), amar ma'ruf.

\section{B. Saran-saran}

Islam sebagai suatu ajaran yang komprehensif telah memberikan suatu landasan berkomunikasi, meskipun belum ada ilmu yang khusus mengkajinya. Namun, etika-etika komunikasi dalam Islam sangat jelas tergambar dan telah dicontohkan langsung oleh Rasulullah Saw yang sudah selayaknya utuk di pelajari dan diamalkan.

\section{DAFTAR PUSTAKA}

Abidin Ass, Djamalul. Komunikasi dan Bahasa Dakwah. Jakarta: Gema Insani Press, 1996.

Arifin, Anwar. Dakwah Kontemporer Sebuah Studi Komunikasi. Yogyakarta: Graha Ilmu, t.th.

Borg, James. Buku Pintar Memahami Bahasa Tubuh terj. Abdul Hamid. Jogjakarta: Think, 2010.

Departemen Agama RI. Jakarta: Sukses Publishing, 2012.

Al-Ismail, Tahia. Tarikh Muhammad; Teladan Perilaku Umat terj. A. Nashir Budiman. Jakarta: Rajagrafindo Persada, 1996.

Jasad, H. Usman Jasad. Dakwah \& Komunikasi Transformatif; Mencari Titik Temu Dakwah dan Realitas Sosial Umat. Makassar: Alauddin University, 2011.

Jumantoro, Totok. Psikologi Dakwah; dengan Aspek-Aspek Kejiwaan yang Qur'ani. Jakarta: Amzah, 2001.

Kasman, Suf. Jurnalistik Universal: Menelusuri Prinsip-Prinsip Dakwah Bi Al-Qalam dalam AlQuran. Jakarta: Teraju, 2004.

Muhammad Said, Nurhidayat. Dakwah \& Efek Globalisasi Informasi. Makassar: Alauddin University, 2001.

Muhyiddin, H. Asep dan Agus Ahmad Safei. Metode Pengembangan Dakwah. Bandung: Pustaka Setia, 2002.

Muis, A. Abdul. Komunikasi Islam. Bandung: Remaja Rosdakarya, 2001. 
Nurjaman, Kadar dan Uman dan Khaerul. Komunikasi \& Publik Relation; Panduan Untuk Mahasiswa, Birokrat, dan Praktisi Bisnis. Bandung: Pustaka Setia, 2012.

Taufik, M. Tata, H. Etika Komunikasi Islam. Bandung; Pustaka Setia, 2012.

Tike, Arifuddin. Etika Komunikasi; Suatu Kajian Kritis Berdasarkan Al-Qur'an. Makassar: Alauddin University, 2012. 